\title{
Polymer packaging materials - friend or foe of the Circular Economy
}

\author{
Zenon Foltynowicz ${ }^{1)}$ \\ DOI: dx.doi.org/10.14314/polimery.2020.1.1
}

\begin{abstract}
Plastic packaging is a product of short-term use and becomes waste after use. For most packages made of homogeneous polymeric material, there is no problem with their recycling. The packaging used for food packaging and storage, for example, multilayer foils, considerably reduces food losses. However, due to their complex multi-polymer structure, it is significantly more difficult to recycle it. Currently, in this case there are almost no technologies that are effective enough to be both cost-effective for recyclers and not burden the environment. Leading companies from the plastics industry in cooperation with food and packaging producers are working on solutions that will improve the suitability for recycling of multi-layer packaging while maintaining high level of food protection. Huge hopes are connected with nanotechnology and nanomaterials that enter the packaging market, mainly nanocomposites, and particularly ideally, if it would be biodegradable bionanocomposites. However, new packaging materials based on nanocomposites are bringing potentially new problems for recycling. The paper presents the issues related to meeting the requirements of Circular Economy by multilayered packaging materials based on traditional polymers and alternative materials of the new generation introduced to the packaging market.
\end{abstract}

Keywords: Circular Economy, multilayer packaging, (bio)nanocomposites packaging.

\section{Materiały opakowaniowe z tworzyw polimerowych - przyjaciel czy wróg Gospodarki o Obiegu Zamkniętym}

Streszczenie: Opakowania z tworzyw polimerowych po krótkotrwałym użyciu stają się odpadem. W wypadku większości opakowań wykonanych z jednorodnych materiałowo tworzyw polimerowych nie ma problemu $z$ ich recyklingiem. Odpowiednio dobrane opakowania stosowane do pakowania i przechowywania żywności w istotnym stopniu zmniejszają straty żywności - przykładem mogą być folie wielowarstwowe. Ze względu jednak na ich złożoną, wielopolimerową strukturę trudno jest poddać je klasycznemu recyklingowi. Obecnie nie ma wystarczająco efektywnych technologii, opłacalnych dla recyklerów i jednocześnie nieobciążających zbytnio środowiska. Czołowe firmy z branży tworzyw polimerowych w porozumieniu z producentami żywności i opakowań pracują nad rozwiązaniami zwiększającymi przydatność do recyklingu opakowań wielowarstwowych z zachowaniem efektywnej ochrony żywności. Ogromne nadzieje wiązano z wkraczającą do opakowalnictwa nanotechnologią i na-

1) Poznan University of Economics and Business, Institute of Quality Science, Department of Non-Food Product Quality and Packaging Development, Al. Niepodległości 10, 61-875 Poznań, Poland.

e-mail: Zenon.Foltynowicz@ue.poznan.pl 
nomateriałami, głównie nanokompozytami, idealnie - biodegradowalnymi bionanokompozytami. Niestety nowe materiały opakowaniowe oparte na nanokompozytach stwarzają nowe problemy w zakresie recyklingu. W artykule przedstawiono zagadnienia związane z wymogami Gospodarki o Obiegu Zamkniętym (GOZ) dotyczącymi wielowarstwowych materiałów opakowaniowych opartych na tradycyjnych polimerach oraz alternatywnych materiałach nowej generacji wprowadzanych na rynek opakowań.

Słowa kluczowe: GOZ, opakowania wielowarstwowe, (bio)nanokompozyty opakowaniowe.

Traditionally, the golden rule of the material design was to have polymers that maintain structural strength, useful characteristics properties even after prolonged use. Longevity of polymers becomes a problem after the end of their useful life cycle because as waste most often are deposited in a landfill or littered in the environment, so they last there for a long time. Environmental issues regarding a very long degradation time of polymers are one of the biggest problems associated with the design and development of new materials, especially in packaging applications [1, 2]. The products packaging made of polymeric materials might be widely used for several decades. Unfortunately, many of them end their useful life after a single-use, contributing to the ever-growing amount of waste. For years, the European Union has been trying to fight this problem by introducing various types of strategies. We had IPP - an Integrated Product Policy, a Europe of "recycling", a Resource Efficient Europe. In 2012, the strategy of bioeconomics, otherwise known as the bioeconomy or the green economy, was pompously introduced [3]. It was trusted that if the large-scale introduction of bioplastics - biodegradable, compostable, generally "organic" - began, the problem of waste packaging materials will be solved. Bioeconomy was a response to the need to implement a Sustainable Development strategy in accordance with the Rio Declaration. It was expected that biodegradable plastics, produced from renewable raw materials or "bioderivatives" (non-oil PE), such as PLA (polylactide), PHB (polyhydroxybutyrate), starch, and cellulose of a new generation, might/will solve the problem of the growing mountains of packaging waste. The bioeconomy strategy has caused a boom in these materials. Many examples of commercialized packaging materials can be provided. Unfortunately, they have not yet replaced conventional packaging materials for several various reasons which will not be discussed here.

After several years of implementation of the Sustainable Development strategy, guidelines for sustainable products, including packaging were developed [4]. Sustainable products are providing environmental, social and economic benefits while protecting public health, prosperity and the environment throughout the life cycle, from the extraction of raw materials to final management. The Sustainable Packaging Coalition was established [5] promoting sustainable packaging.

All these activities are aimed at ensuring the protection of the packaged product and reducing the amount of waste. As part of the implementation of the Sustainable
Development strategy, it was stated that the traditional, linear consumption model should be abandoned and instead a closed loop approach should be applied. And so the idea of a new economy was born, commonly known as the Circular Economy (CE) [6]. As part of this trend, the slogans "Europe without waste" or "no packaging solution" appeared [7]. The European Union quickly got involved in the $\mathrm{CE}$, seeing it as an opportunity to support the sustainable development strategy [8]. The European Commission (EC) set a target of 2030 to increase recycling of plastic packaging stating that "the only long term solution is to reduce plastic waste by recycling and reusing more" [9]. The EC committed to "develop a strategy on the challenges posed by plastics in the entire value chain, taking into account their entire life cycle".

\section{PACKAGING IN A NEW PLASTIC STRATEGY}

A European Strategy for Plastics in a Circular Economy [10] is a derivative of Ellen MacArthur Foundation The New Plastics Economy: Rethinking the future of plastics [11]. Among the strategy points, several of them directly concern packaging. The assumptions of the strategy are already generally known. The strategy's goal is, among others, to ensure that all plastic packaging will be recyclable by 2030 [9]. It is also expected to contribute to achieving the goals of Sustainable Development and the Paris Agreement by $2030[9,10]$. The challenges are really significant because $26 \%$ of total plastics production is used for packaging $[12,13]$. It is estimated that $95 \%$ of the value of plastic packaging materials, i.e. from 70 to 105 billion $€$ per year, is lost in the economy after a very short cycle of their first use [13]. The demand for recycled plastics currently only accounts for around $6 \%$ of the demand for plastics in Europe.

It has been estimated that the production of plastics and the incineration of plastic waste generates about 400 million tons of $\mathrm{CO}_{2}$ per year worldwide. The using of recycled plastics can reduce the dependence on fossil fuel production for plastics production and reduce $\mathrm{CO}_{2}$ emissions. According to estimates [14], the potential annual energy savings that could be achieved by recycling all plastic waste in the world correspond to about 3.5 billion barrels of oil per year.

The CE (Circular Economy) strategy assumes that by 2030 all plastic packaging placed on the EU market must be re-used or recycled cost-effectively. The assumptions are right, but are they feasible? There are approx. 100 re- 
cycling technologies. The CE assumes that together with The European Food Safety Authority (EFSA) they will be verified in terms of their suitability for the production of recyclable materials suitable for contact with food. The problem is that most recycling methods lead not only to at least $10 \%$ material losses but also to $10 \%$ material quality loss [15]. According to Solis [16], in the current system, plastic packaging can be recycled up to seven times, after which the polymers will be degraded to such an extent that they can no longer be used. Therefore, solutions are sought for the design of packaging from biodegradable and compostable plastics that will meet the CE requirements. The problem was described in several papers at the 4th Congress of the Packaging Industry [17, 18].

However, let's look at this issue from the perspective of the development of packaging materials and functions performed by packaging. The functions of packaging, which are generally divided into basic (primary) and additional (secondary), have been described in several studies $[19,20]$. However, the old "3Ps" functions (Protect, Preserve and Promote) are now extended to include functions such as Trace, Authenticate, Inform, Add Value, Secure and Reduce Waste. As the demand for improved basic and additional functions increases, the complexity of the packaging also increases [21]. Initially, the packaging consisted of a single material. In many cases, this concept works well, for example in the case of glass jars, PET [poly(ethylene therephthalate)] beverage bottles or metal cans. However, each of these materials has limitations that inhibit its wider use: glass is heavy and brittle, PET does not provide sufficient gas barrier for many products, and the metal is not transparent. By combining different materials, it is possible to develop the concept of an ideal packaging that meets most packaging requirements [22]. This applies mainly to polymeric materials.

Multimaterial packaging is packaging made of at least two different materials that cannot be separated by hand or by simple mechanical methods. Examples of multimaterial packaging - multimaterial systems - were described in Annex 7 of the European Commission Decision 97/129/EC of 28 January 1997, establishing a system for identifying packaging materials. Paradoxically, packaging made of various polymers is not considered as multimaterial! These include metalized films, i.e. typical packaging polymers coated mostly with aluminum, e.g. PE/Al, PP/Al, PET/Al, PS/Al, and paper and cardboard coated with them. In packaging, many multilayer films are used, both double-layered, e.g. PE/PP, PE/PA or multilayer PET/ EVOH/PET, PET/PA/PET (where: PA - polyamide, EVOH - ethylene vinyl alcohol). Multilayer packaging materials based on polymers, i.e. laminates, composites, are commonly used to combine the respective best properties of different polymers. Thanks to this approach, functional packaging is created that allows sufficient protection of sensitive food products and thus a prolonged period of their durability. It should also be mentioned that multilayer films as packaging material have helped to prevent the amount of food waste and thus reduce the global hunger problem as an excellent material for protecting stored food, especially in poor countries!

However, due to the low recycling susceptibility, most of the used multilayered packaging materials are usually burnt or landfilled or littered in oceans. This is against the assumptions of the CE idea. Recently, Kaiser [23] presented the possibilities of recycling multilayer polymer packaging materials discussing a range of different possible methods for their recycling. It was found that so far no solution is available on an industrial scale. For the recycling of multilayer packaging waste, a delamination or compatibilization process is proposed. However, other authors [24] state that most of these methods have a low TRL (technology readiness levels) level. Therefore, intensive $R \& D$ works are required to meet $C E$ requirements. There are more and more examples of such solutions [25]. An alternative to composites based on traditional polymeric materials is to be biocomposites, most often biodegradable. However, whether their use and especially the final management, can be reconciled with CE principles?

The current review of composite materials for packaging can be found in the "Composites Materials for Food Packaging" monograph, which recently appeared on the publishing market [26]. In addition to traditional composite materials based on commonly used polymers: PE, PP, PET, PS (polystyrene), a lot of space has been devoted to nanocomposites, new generation materials based on nanomaterials, including nanobiocomposites also their biodegradable version. Let's consider some of the aspects of biodegradable materials in the frame of CE on the PLA example. Synthetic poly(lactic acid) (PLA) is a flagship biodegradable biobased material, which has already found application as a packaging material [26]. In order to improve the performance of PLA, additives in the form of fillers or reinforcements are introduced. Depending on the origin and biodegradability of these components, PLA composites can be divided into biocomposites and "green" composites. These include PLA. This first group includes composites with petroleum or inorganic or natural fiber fillers or reinforcements. The latter, like the PLA itself, are considered to be fully biodegradable. In addition to conventional PLA applications, e.g. in the form of a film, it can also be a matrix of nanocomposites. Hybrid PLA nanocomposites are obtained by adding nanofillers or nanoreinforcements, either organic or inorganic. They allow obtaining even better parameters than show conventional composites.

PLA has been introduced to the market as a renewable material, which can be applied as a fertilizer after its use as a packaging material. Recently, many authors have praised bioplastic packaging materials as a future for a Circular Economy [18, 27]. After initial delight with this material many years ago [28], some questions about the actual state appear. Some real, critical facts about PLA according to FP International [29] are presented below.

PLA is $100 \%$ biobased, made from fermented plant starch. Producers promise PLA to be free of toxins and 
carbon neutral. However, while looking at PLA's production process, 'crops for plastic' needs to be cultivated to produce the fermented plant starch. These crops have to be converted into the lactide and this process still produces carbon emission.

The plant starch for PLA production is often made from either corn or potato, which are both essential food commodities. The rapidly gained popularity caused an increase in demand for non-food use of corn. According to European Bioplastics, in 2018 agricultural production for all bioplastics accounted for only $0.016 \%$ of the arable land area [30]. It seems that there is currently no competition between renewable raw materials for food, feed and bioplastic production. However, a similar situation may be repeated as for the production of ethanol from maize. Namely, in 1980, less than one percent of corn was used for ethanol production. However, in 2010/2011, 36\% of corn produced in the United States was used to manufacture ethanol [31]. This influences on the global price of corn. PLA may be a solution for the plastic waste issue, but it contributes to the problem of food shortage in the less wealthy parts of the world. Thus PLA it solving one issue, but worsening another, what is an unsustainable solution.

It remains to consider the problem of the final management of PLA as well as nanocomposites based on it. Regardless of the many advantages of nanocomposites based on the PLA matrix, these materials create challenges in terms of safety and final management. Their recycling or composting requires not only separation from the packaging waste stream but also special installations. Why? According to the European regulations [32], compostable material must be smaller than $2 \mathrm{~mm}$ for more than $90 \%$ of its' original dry mass after 12 weeks of degradation. PLA only breaks down in a specific controlled environment of $58^{\circ} \mathrm{C}$. This is the same drawback of this process as for other biodegradable materials. So far most countries haven't developed the appropriate composting facilities, which will make difficult to properly dispose of PLA based products.

In the case when PLA ends up in landfill, there may not be enough amount of oxygen for its degradation process. In such conditions, PLA may start to expel methane, which has 38 times larger GHG index than $\mathrm{CO}_{2}$.

This new and fashionable bio-based alternative to fossil fuel-based plastics looks too good to be true and to fulfill CE requirements.

However, due to the importance of polymer for CE, scientists are interested in the concept of designing materials based on a cradle-to-cradle life cycle concept [33] or "design to degrade" [34] as well as with an intrinsically infinite recyclability [35].

\section{CONCLUSIONS}

$\mathrm{CE}$ distinguishes between the technical and biological cycles [6]. In the case of materials obtained from renewable raw materials, particular attention is paid to their biodegradability. In this way, the contribution that renewable materials and their reuse and recycling can make to improving the circular economy and environmental performance is often neglected. The EU strategy on plastics draws attention to both aspects.

The problem of nanobiocomposites for packaging is very complex, especially in the context of CE. Morganti [36] states that CE opens new horizons for nanobiocomposites, especially those obtained from waste materials. The Swedish authors of the latest report on renewable materials in the $\mathrm{CE}$ are more careful in their judgments and even a bit skeptical [37].

The EC's plastics strategy assumes that "all plastic packaging will be reusable or recyclable until 2030." However, will all materials meet these requirements? Until now, there is no real industrial method of recycling packaging nanobiocomposites, even if they would be suitable for it. However, technological advances that have occurred and are still progressing in the field of nanobiocomposite packaging are so large and irreversible that they can not be wasted by any directive. Nanobiocomposites are the future of packaging materials and will continue to grow, regardless of the bioeconomy or circular economy. There are more and more reports that the plastics industry is looking now-a-days for solutions that will meet the requirements of CE [17, 18, 25, 37].

\section{REFERENCES}

[1] Licciardello F.: Trends in Food Science \& Technology 2017, 65, 32.

[2] Pauer E., Wohner B., Heinrich V., Tacker M.: Sustainability 2019, 11, 925.

[3] http://bio-based.eu/?did=120804\&vp_edd_ac$\mathrm{t}=$ show_download (availability date 16.07.2019).

[4] Foltynowicz Z.: "The sustainable commodity and products for circular economy", Commodity Science in a Changing World: 20th IGWT Symposium, Publishing house "Science and Economics"(Ed. Pahsova S.), Varna 2016, p. 83.

[5] The Sustainable Packaging Coalition ${ }^{\circledR}$, https://sustainablepackaging.org (availability date 11.08.2018).

[6] "Towards the Circular Economy vol. 1", Ellen MacArthur Foundation, https://www.ellenmacarthurfoundation.org/assets/downloads/publications/Ellen-MacArthur-Foundation-Towardsthe-Circular-Economy-vol.1.pdf (availability date 16.07.2019).

[7] Foltynowicz Z., Stróżyk K.: „Europa bez odpadów” in "Kompleksowe Zarządzanie Gospodarką Odpadami" (Ed. Manczarski P.), PZIiTS, Poznań 2015, p. 25.

[8] http://ec.europa.eu/environment/circular-economy/ index_en.htm (availability date 16.07.2019).

[9] https://ec.europa.eu/unitedkingdom/news/tackling-plastic-pollution-commission-sets-2030-target- 
make-all-plastic-packaging-recyclable_en (availability date March 2019).

[10] https://ec.europa.eu/commission/sites/beta-political/ files/plastics-factsheet-challenges-opportunities en.pdf (availability date 16.07.2019).

[11] https://www.ellenmacarthurfoundation.org/publications/the-new-plastics economyrethinking-thefuture-of-plastics (availability date 26.02.2019)

[12] http://ec.europa.eu/environment/circular-economy/ index_en.htm (availability date 16.07.2019).

[13] https://www.ellenmacarthurfoundation.org/publications/the-new-plastics-economyrethinking-thefuture-of-plastics (availability date 26.02. 2019).

[14] Rahimi A., García J.M.: Nature Reviews Chemistry 2017, 1, 0046.

[15] Merrild H., Larsen A.W., Christensen T.H.: Waste Management 2012, 32, 1009.

[16] https://kth.diva-portal.org/smash/get/diva2:1233729/ FULLTEXT01.pdf (availability date 11.08.2018)

[17] „Transformacja przemysłu opakowań w kierunku gospodarki o obiegu zamkniętym" (Ed. Wasiak W.), Polska Izba Opakowań, Warszawa 2018, p. 21, 137, 190, 200, 287.

[18] Bartkowiak A.: „Biotworzywa jako szansa odpowiedzi na wymagania GOZ w zakresie opakowań z tworzyw polimerowych", Conference Rekopol: Opakowania w obiegu zamkniętym - Jakich opakowań szuka przemysł?", Warszawa, 6 marca 2019.

[19] Korzeniowski A., Skrzypek M., Szyszka G.: „Opakowania w systemach logistycznych", ILiM, Poznań 2010.

[20] Lisińska-Kuśnierz M., Ucherek M.: „Współczesne opakowania", Wydawnictwo Naukowe Polskiego Towarzystwa Technologów Żywności, Kraków 2003.

[21] "PlasticsEurope, Plastic Packaging: Born to Protect", PlasticsEurope Association of Plastics Manufacturers, Brussels, Belgium 2012.
[22] Morris B.A.: "The Science and Technology of Flexible Packaging. Multilayer Films from Resin and Process to End Use", Elsevier: Amsterdam 2016.

[23] Kaiser K., Schmid M., Schlummer M.: Recycling 2018, 3, 1. http://dx.doi.org/10.3390/recycling3010001

[24] Rybicka J., Tiwari A., Leeke G.A.: Journal of Cleaner Production 2016, 112, 1001.

[25] Hong A., Chen E.Y.Y.: Green Chemistry 2017, 8, 59.

[26] "Composites Materials for Food Packaging" (Eds. Cirillo G., Kozlowski M.A., Spizzirri U.G.), John Wiley \& Sons, Inc. and Scrivener Publishing LLC, Beverly, MA 2018.

[27] Dobrucka R.: LogForum 2019, 15, 129.

[28] Foltynowicz Z., Jakubiak P.: Polimery 2002, 47, 769.

[29] https://fp-sustainability.eu/uncategorized/why-plais-not-the-answer/ (availability date 27.07.2019)

[30] Bioplastics market data; https://www.european-bioplastics.org/market/ (availability date 13.08.2019).

[31] Rattray J.: UW-L Journal of Undergraduate Research 2012, $X V, 1$.

[32] European Standard EN 13432:2000 “Requirements for packaging recoverable through composting and biodegradation - Test scheme and evaluation criteria for the final acceptance of packaging".

[33] Bakker C.A., Wever R.: International Journal of Sustainable Engineering 2010, 3, 2.

[34] Albertsson A.C., Hakkarainen M.: Science 2017, 358, 872.

[35] Zhu J.B., Watson E.M., Tang J., Chen E.Y.X.: Science 2018, 360 (6387), 398.

[36] Morganti P.: International Journal of Biotechnology for Wellness Industries 2016, 5, 1.

[37] Harris S., Staffas L., Rydberg T., Eriksson E.: "Renewable materials in the Circular Economy" IVL Swedish Environmental Research Institute 2018, Report number C 296, ISBN 978-91-88787-30-9.

Received 29 VII 2019

\section{Rapid Communications}

Przypominamy P.T. Autorom, że publikujemy artykuły typu Rapid Communications. Prace oryginalne wyłącznie w języku angielskim o objętości $4-5$ stron maszynopisu z podwójną interlinią (plus ewentualnie 2-3 rysunki lub 1-2 tabele), którym umożliwiamy szybką ścieżkę druku (ok. 4 miesiące od chwili ich otrzymania przez Redakcję). Artykuł należy przygotować wg wytycznych zamieszczonych we wskazówkach dla Autorów. 